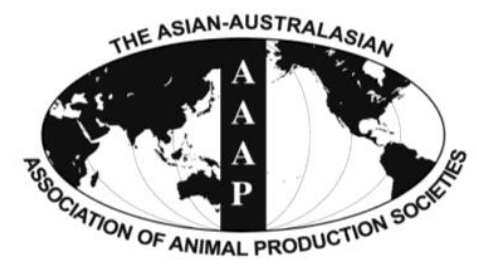

Asian-Aust. J. Anim. Sci.

Vol. 25, No. 11 : 1588-1594 November 2012

http://dx.doi.org/10.5713/ajas.2012.12192

www.ajas.info

pISSN 1011-2367 elSSN 1976-5517

\title{
Effects of Replacement of Fish Meal by Soy Protein Isolate on the Growth, Digestive Enzyme Activity and Serum Biochemical Parameters for Juvenile Amur Sturgeon (Acipenser schrenckii)
}

\author{
Q. Y. Xu*, C. A. Wang, Z. G. Zhao and L. Luo \\ Heilongjiang River Fisheries Research Institute of Chinese Academy of Fishery Sciences, Harbin 150070, China
}

\begin{abstract}
An 8-wk experiment was conducted to evaluate the effect of replacing fish meal (FM) with soy protein isolate (SPI) on the growth, digestive enzyme activity and serum biochemical parameters of juvenile Amur sturgeon (Acipenser schrenckii). SPI was used to replace $0,25,50,62.5,75,87.5,100 \%$ of dietary FM and 100\% replacement supplemented crystalline amino acid. Healthy sturgeon with an average initial weight of $26.38 \pm 0.24 \mathrm{~g}$ were randomly assigned to 24 aquaria ( 8 treatments with triplicates each) at an initial stocking density of 11 fish per aquarium and cultured for 8 wks. The results showed that $75.00 \%$ or more substitution resulted in a poor weight gain rate, feed conversion ratio and survival rate compared to that of fish fed the control diet $(p<0.05)$, whereas no significant differences were observed between diets of $25.00 \%$ to $62.50 \%$ substitution. Protease, lipase and amylase activity in foregut, mid-gut and hindgut were significantly $(\mathrm{p}<0.05)$ decreased by diets where SPI replacement levels were $62.50 \%$ or more. Levels of serum total protein (TP) and globulin decreased significantly from 21.03, 10.34 to $14.05,5.63 \mathrm{~g} / \mathrm{L}$ with the increasing dietary SPI $(\mathrm{p}<0.05)$, but alkaline phosphatase activity significantly increased $(\mathrm{p}<0.05)$. In addition, supplemental crystalline amino acid in the FM absence diet did not improve growth performance, intestine digestive enzyme activities and serum biochemical parameters. In conclusion, the results from this study showed adverse effects of inclusion of SPI in diets on growth performance, feed utilization and serum biochemical parameters in juvenile Amur sturgeon. Based on WGR and replacement ratio presented in this report, a 57.64\% replacement level was recommended. (Key Words: Soy Protein Isolate, Acipenser schrenckii, Growth, Digestive Enzyme Activity, Serum Biochemical Parameters)
\end{abstract}

\section{INTRODUCTION}

Amur sturgeon, Acipenser schrenckii Brant, is a riverine resident sturgeon species in the Amur River, which has become one of the popular sturgeon culture species in China (Zhuang, 2002), however there have been few nutritional studies for evaluations of alternative dietary protein sources. Fish meal (FM), owing to its nutritional quality, is a widely used and expensive protein component of fish diets (Carter and Hauler 2000; Naylor et al., 2000). Partial replacement of fish meal by cheaper ingredients of either animal or vegetable origin in aquatic animal feed is necessary because of the rising cost and uncertain availability of fish meal (Kaushik, 1990; Morales et al., 1994). Plant protein sources, which are more consistently available and cheaper to produce than FM, have been

\footnotetext{
* Corresponding Author: Q. Y. Xu. Tel: +86-451-84861322-841, Fax: +86-451-84604803, E-mail: xuqiyou@ sina.com Submitted Mar. 27, 2012; Accepted Jun. 13, 2012; Revised Jul. 31, 2012
}

extensively used in combination with FM in practical feed. Among the plant protein sources considered, soybean protein has been preferentially used for replacement of FM due to its high protein content, fairly balanced amino acid profile (Min et al., 2009; Ao et al., 2010) and global presence. Methionine and lysine are the most limiting amino acids in diets containing high levels of soybean meal (SBM). El-Saidy and Gaber (1997, 2002) reported that soybean meal supplemented with $1.00 \%$ methionine or $1.00 \%$ methionine and $0.50 \%$ lysine can totally replace FM in Nile tilapia diets. The substitution of FM with plant protein could have a positive effect on production costs (Hardy, 1996). However, the presence of antinutritional factors like enzyme inhibitors often limit the use of plant ingredients in fish feed as they affect protein digestibility, causing adverse physiological effects and reducing growth (Olli et al., 1994). An enzyme inhibitor is any substance that reduces the measured rate of an enzyme-catalyzed reaction (Whitaker, 1994). Growth is often been reduced in fish fed diets where soybean meal replaces all the FM (Shiau et al., 
1987; Reigh and Ellis, 1992; Floreto et al., 2000).

Soy protein isolate (SPI) contains more than $80 \%$ crude protein and has a fairly balanced amino acid profile, but there is little information about its potential as a replacement for FM in diets formulated for sturgeon. The present study was undertaken to observe the effects of: i) graded levels of replacement of FM by SPI in present diets, and ii) total feeding of SPI without FM with and without supplements of crystalline amino acid on the growth, digestive enzyme activity and serum biochemical parameters of juvenile Amur sturgeon.

\section{MATERIALS AND METHODS}

\section{Experimental design and diets}

Juvenile Amur sturgeon were obtained from the Fang Shan Station of the Chinese Academy of Fishery Sciences and used for the feeding trial. The fish were raised in glass aquaria (200 L water) which were connected to an automatically controlled recirculation system and every three aquaria were connected to a separate recycling system and were supplied with aerated water which was filtered through zeolum, corallite and activated carbon. The fish were acclimated in glass aquaria and fed with control diet 3 times daily for 2 wks. Next, healthy fish with an average initial weight of $26.38 \pm 0.24 \mathrm{~g}$ were randomly assigned to
24 aquaria (8 treatments with triplicates each) at an initial stocking density of 11 fish per aquarium and cultured for 8 wks.

SPI, alkali-extracted, acid-precipitated at its isoelectric point, and dried to $10 \%$ moisture, was obtained from Harbin Hi-Tech Soybean Food Co., LTD. SPI was used to replace 0, $25,50,62.5,75,87.5,100 \%$ of dietary FM and 100\% replacement supplemented crystalline amino acid. The experimental diet formulation and proximate composition are shown in Table 1. All diets were individually blended in a mixer and then homogenized after fish oil and soybean lecithin were added. Pellets $1.5 \mathrm{~mm}$ diameter were then prepared using a meat grinder and air-dried at room temperature, and maintained at $-20^{\circ} \mathrm{C}$ until further use.

Fish were fed by hand, three times daily at 08:00, 14:00, and 18:00 $\mathrm{h}$ at a rate of $4.0 \%$ body weight per day. The fish in each aquarium were weighed at the start and every 2 wks during the $8 \mathrm{wks}$ of the experimental period. Feeding was stopped $36 \mathrm{~h}$ before weighing. Water temperature and $\mathrm{pH}$ value were constant $\left(23^{\circ} \mathrm{C} ; \mathrm{pH} 7.8\right)$ during the experimental period, and $75 \%$ of the water was exchanged at 2,4 and 6 wk to maintain water quality. Dissolved oxygen was maintained at $7.7 \mathrm{mg} / \mathrm{L}$, and ammonia-N concentrations were not more than $0.05 \mathrm{mg} / \mathrm{L}$.

Fish in each aquarium were counted and weighed at the end of the experiment for the analysis of weight gain rate

Table 1. Formula and nutritional level of the experiment feed as $\mathrm{g} / 100 \mathrm{~g}$ dry matter

\begin{tabular}{|c|c|c|c|c|c|c|c|c|}
\hline Ingredient & Diet 1 & Diet 2 & Diet 3 & Diet 4 & Diet 5 & Diet 6 & Diet 7 & Diet 8 \\
\hline Wheat flour & 22.3 & 22.3 & 22.3 & 22.3 & 22.3 & 22.3 & 22.3 & 22.3 \\
\hline Fish meal & 40 & 30 & 20 & 15 & 10 & 5 & 0 & 0 \\
\hline SPI & 0 & 7.4 & 14.8 & 18.5 & 22.2 & 25.9 & 29.6 & 29.6 \\
\hline Blood meal & 5 & 5 & 5 & 5 & 5 & 5 & 5 & 5 \\
\hline Wheat gluten & 5 & 5 & 5 & 5 & 5 & 5 & 5 & 5 \\
\hline Corn gluten & 10 & 10 & 10 & 10 & 10 & 10 & 10 & 10 \\
\hline Soy oil & 7 & 7 & 7 & 7 & 7 & 7 & 7 & 7 \\
\hline Soy lecithin & 2 & 2 & 2 & 2 & 2 & 2 & 2 & 2 \\
\hline Fish oil & 7.5 & 8.2 & 9 & 9.4 & 9.8 & 10.2 & 10.6 & 10.6 \\
\hline $\mathrm{Ca}\left(\mathrm{H}_{2} \mathrm{PO}_{4}\right)_{2}$ & 0 & 0 & 1.2 & 1.6 & 2.2 & 2.7 & 3.2 & 3.2 \\
\hline L-methionine & 0 & 0 & 0 & 0 & 0 & 0 & 0 & 0.26 \\
\hline L-lysine & 0 & 0 & 0 & 0 & 0 & 0 & 0 & 0.5 \\
\hline Threonine & 0 & 0 & 0 & 0 & 0 & 0 & 0 & 0.22 \\
\hline Cellulose & 0 & 1.9 & 2.5 & 3 & 3.3 & 3.7 & 4.1 & 3.12 \\
\hline Premix* & 1.2 & 1.2 & 1.2 & 1.2 & 1.2 & 1.2 & 1.2 & 1.2 \\
\hline Total & 100 & 100 & 100 & 100 & 100 & 100 & 100 & 100 \\
\hline \multicolumn{9}{|c|}{ Proximate analysis } \\
\hline Crude protein & 44.01 & 43.93 & 41.96 & 41.97 & 42.76 & 42.13 & 45.72 & 46.84 \\
\hline Crude lipid & 16.33 & 16.81 & 16.82 & 16.62 & 16.21 & 16.22 & 16.16 & 16.26 \\
\hline
\end{tabular}

* Premix $12.00 \mathrm{~g} / \mathrm{kg}$, including: VC $1.00 \mathrm{~g} / \mathrm{kg}$; Choline $2.00 \mathrm{~g} / \mathrm{kg}$; Antioxidant $0.25 \mathrm{~g} / \mathrm{kg}$; Antimildew $0.50 \mathrm{~g} / \mathrm{kg}$; Betaine $1.00 \mathrm{~g} / \mathrm{kg} ; \mathrm{MgSO}{ }_{4} 3.00 \mathrm{~g} / \mathrm{kg}$; Vitamin premix $1.00 \mathrm{~g} / \mathrm{kg}^{* *} ;$ Mineral premix $2.00 \mathrm{~g} / \mathrm{kg}^{*} * *$.

** Vitamin premix includes: Vitamin E 60 mg/kg; Vitamin K 5 mg/kg; Vitamin A 15, 000 IU/kg; Vitamin D 3 3,000 IU/kg; Vitamin B 15 mg/kg; Vitamin $\mathrm{B}_{2} 30 \mathrm{mg} / \mathrm{kg}$; Vitamin $\mathrm{B}_{6} 15 \mathrm{mg} / \mathrm{kg}$; Vitamin B ${ }_{12} 0.5 \mathrm{mg} / \mathrm{kg}$; Nicotinic acid $175 \mathrm{mg} / \mathrm{kg}$; Folic acid $5 \mathrm{mg} / \mathrm{kg}$; Inositol 1,000 mg/kg; Pantothenic acid 50 $\mathrm{mg} / \mathrm{kg}$; Biotin $2.50 \mathrm{mg} / \mathrm{kg}$.

*** Mineral premix includes: Fe $25.00 \mathrm{mg} / \mathrm{kg}$; Cu $3.00 \mathrm{mg} / \mathrm{kg} ; \mathrm{Mn} 15.00 \mathrm{mg} / \mathrm{kg} ; \mathrm{Zn} 60.00 \mathrm{mg} / \mathrm{kg} ; \mathrm{Se} 0.30 \mathrm{mg} / \mathrm{kg} ; \mathrm{I} 0.60 \mathrm{mg} / \mathrm{kg}$. 
Table 2. Effects of replacement of fish meal with SPI on the growth performance and feed conversion ratio of Amur sturgeon*

\begin{tabular}{|c|c|c|c|c|c|c|c|c|}
\hline Parameters & Diet 1 & Diet 2 & Diet 3 & Diet 4 & Diet 5 & Diet 6 & Diet 7 & Diet 8 \\
\hline IBW (g) & $26.43 \pm 0.23^{\mathrm{a}}$ & $26.54 \pm 0.25^{\mathrm{a}}$ & $26.34 \pm 0.42^{\mathrm{a}}$ & $26.23 \pm 0.31^{\mathrm{a}}$ & $26.55 \pm 0.56^{\mathrm{a}}$ & $26.31 \pm 0.37^{\mathrm{a}}$ & $26.36 \pm 0.51^{\mathrm{a}}$ & $26.28 \pm 0.56^{\mathrm{a}}$ \\
\hline FBW (g) & $72.53 \pm 0.12^{\mathrm{b}}$ & $73.57 \pm 0.14^{\mathrm{b}}$ & $71.58 \pm 0.11^{\mathrm{b}}$ & $70.68 \pm 0.13^{\mathrm{b}}$ & $64.25 \pm 0.13^{\mathrm{a}}$ & $59.51 \pm 0.18^{\mathrm{a}}$ & $56.08 \pm 0.14^{\mathrm{a}}$ & $56.31 \pm 0.13^{\mathrm{a}}$ \\
\hline WGR (\%) & $174.42 \pm 5.13^{\mathrm{d}}$ & $177.20 \pm 8.35^{\mathrm{d}}$ & $171.75 \pm 7.11^{\mathrm{d}}$ & $169.46 \pm 9.41^{\mathrm{d}}$ & $141.99 \pm 11.64^{\mathrm{c}}$ & $126.19 \pm 7.26^{\mathrm{b}}$ & $112.75 \pm 12.27^{\mathrm{a}}$ & $114.27 \pm 8.17^{\mathrm{a}}$ \\
\hline FCR & $1.69 \pm 0.14^{\mathrm{a}}$ & $1.64 \pm 0.13^{\mathrm{a}}$ & $1.69 \pm 0.02^{\mathrm{a}}$ & $1.76 \pm 0.12^{\mathrm{a}}$ & $2.13 \pm 0.18^{\mathrm{b}}$ & $2.41 \pm 0.14^{\mathrm{c}}$ & $2.73 \pm 0.15^{\mathrm{d}}$ & $2.71 \pm 0.01^{\mathrm{d}}$ \\
\hline Survival (\%) & $96.97 \pm 5.25^{\mathrm{c}}$ & $93.94 \pm 5.25^{\mathrm{bc}}$ & $90.91 \pm 9.09^{\mathrm{bc}}$ & $93.94 \pm 5.25^{\mathrm{bc}}$ & $81.82 \pm 0.00^{\mathrm{ab}}$ & $75.76 \pm 5.25^{\mathrm{a}}$ & $72.73 \pm 9.09^{\mathrm{a}}$ & $75.76 \pm 13.89^{\mathrm{a}}$ \\
\hline
\end{tabular}

* Values are mean \pm standard deviation. Means in the same row with different superscripts are significantly different $(\mathrm{p}<0.05)$.

(WGR), feed conversion ratio (FCR) and survival rate which were determined using the following equations:

$$
\begin{aligned}
& \text { FCR }(\%)=\mathrm{C} /(\mathrm{FBW}-\mathrm{IBW}) \times 100 \\
& \text { WGR }(\%)=(\mathrm{FBW}-\mathrm{IBW}) / \mathrm{IBW} \times 100 \\
& \text { Survival }(\%)=(\mathrm{N} 2 / \mathrm{N} 1) \times 100
\end{aligned}
$$

FBW and IBW are final body weight and initial body weight, respectively. $\mathrm{C}$ is the total feed consumed, and N2 and $\mathrm{N} 1$ are the final and initial number of fish, respectively.

\section{Sample collection and analysis}

After 8 wks of the feeding trial, 3 fish were collected from each aquarium $36 \mathrm{~h}$ after the last feeding. Intestines were removed and detached foregut, mid-gut and hindgut, and stored at $-80^{\circ} \mathrm{C}$ until analysis. After removal, the intestine was separately homogenized in 10 volumes (w/v) of ice-cold physiological saline by an electric homogenizer (FJ-200CL; Shanghai, China). Homogenates were centrifuged at $4,000 \mathrm{~g}$ for $30 \mathrm{~min}$ at $4^{\circ} \mathrm{C}$, the supernatants were collected and frozen in liquid nitrogen, and then stored at $-80^{\circ} \mathrm{C}$. The protease activity was measured by the method of Liu et al. (1991) using Folin-phenol reagent. Lipase activity was determined according to a modified method of Gjellesvik et al. (1992) using 4-nitrophenyl caproate (4NPC) dissolved in ethanol and amylase activity was quantified using a solution to reveal non-hydrolyzed starch (Liu et al., 1991). One unit of protease activity was defined as $1 \mu \mathrm{g}$ tyrosine liberated by hydrolyzing casein in $1 \mathrm{~min}$ at $37^{\circ} \mathrm{C}$. One unit of lipase activity was defined as the amount of enzyme that catalyzed the release of $1 \mu \mathrm{g}$ of fatty acids in $1 \mathrm{~min}$ at $37^{\circ} \mathrm{C}$. One unit of amylase activity was defined as $10 \mathrm{mg}$ amylum was hydrolyzed by $100 \mathrm{ml}$ enzyme solution in $30 \mathrm{~min}$ at $37^{\circ} \mathrm{C}$. Digestive enzyme activities were expressed as enzyme activity per gram intestine weight.

After weighing, blood samples of three sturgeons from each aquarium were used to measure serum total protein (TP), globulin (GLB), albumin (ALB) content and alkaline phosphatase (ALP) activity. Blood samples were obtained from the caudal vein using a 5-ml syringe with a $0.7 \times 32$ needle, pooled in a $1.5 \mathrm{ml}$ centrifuge tube, and then centrifuged at 4,000 $\mathrm{g}$ for $10 \mathrm{~min}$. Serum samples were separated and held at $-80^{\circ} \mathrm{C}$. TP, ALB, GLB and ALP activity was measured using Automatic biochemical analyzer (Beckmann ProCX4, Germany). TP and ALB was measured by the chemical methods, GLB was calculated by the results of TP minus ALB, and ALP activity was measured by the performance rate method.

\section{Statistical analysis}

An analysis of one-way variance (ANOVA) was performed on the data using the SAS ANOVA procedure (SAS, 1993). Duncan's Multiple Range Test (Duncan, 1955) was used to compare differences among individual means. Treatment effects were considered to be significant at $\mathrm{p}<0.05$. Data in the text and in the tables are expressed as mean \pm standard deviation. The replacement level was estimated using the WGR and replacement ratio applying the broken line response methods, as suggested by Zeitoun et al. (1976).

\section{RESULTS}

Fish fed diets at the $0,25,50$ and $62.5 \%$ substitution grew actively throughout the experiment, with no significant differences in WGR among these treatments ( $p>0.05$ ), whereas fed diets at the 75, 87.5 and 100\% substitution exhibited significant reductions in WGR $(\mathrm{p}<0.05)$ compared to FM diet (Table 2). Survival rate were significantly decreased while FCR increased at the $75 \%$ to $100 \%$ substitution $(\mathrm{p}<0.05)$. Supplemental crystalline amino acid in $100 \%$ SPI diet showed no significant effect on WGR, survival and FCR $(p>0.05)$. The growth response data calculated by the broken line analysis showed that the breakpoint was derived at $57.64 \%$ replacement level (Figure 1).

The activities of protease, lipase and amylase in the foregut, mid-gut and hindgut of sturgeon were similar among fish fed diets at the 0,25, 50 and $62.5 \%$ substitution ( $>0.05)$ (Table 3). Furthermore, these digestive enzyme activities were all significantly depressed with increasing levels of SPI replaced FM (75, 87.5 and 100\% substitution), while the supplementation of L-lysine, L-methionine and DL-threonine in diet did not relieve this tendency $(p>0.05)$.

It was evident that the levels of serum TP was 


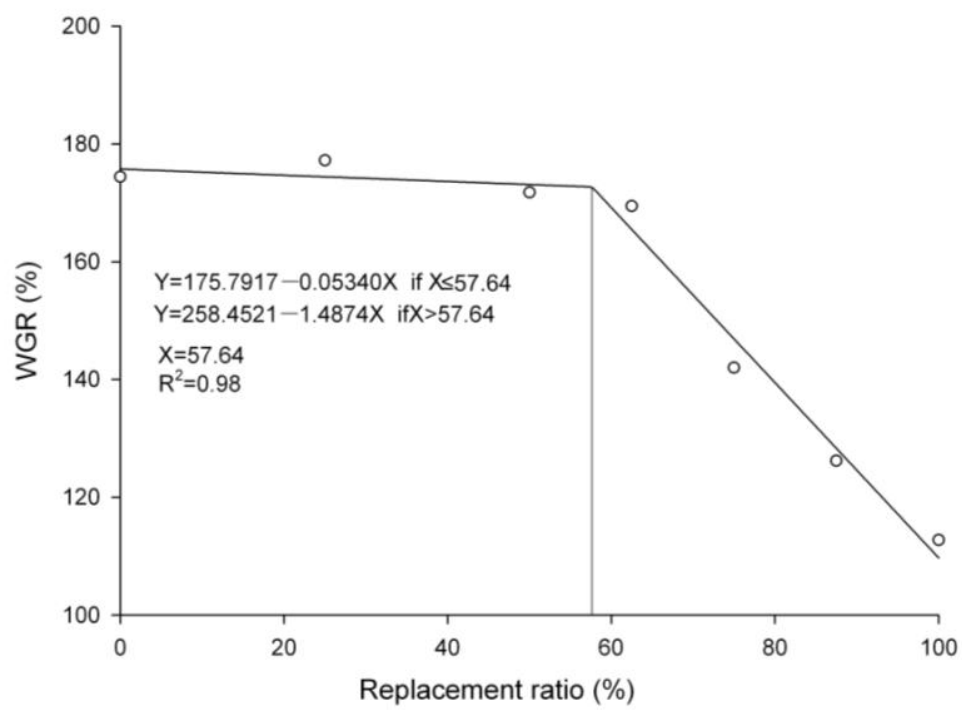

Figure 1. The replacement level was estimated using the WGR and replacement ratio applying the broken line response methods.

significantly decreased with increasing dietary SPI over $50 \%$ substitution (Table 4). Serum GLB also followed the same tendency. The levels of ALB were similar, and no significant difference was observed $(p>0.05)$. While ALP activity significantly increased with increasing dietary SPI over $50 \%$ substitution $(\mathrm{p}<0.05)$. Furthermore, the addition of DL-methionine, L-lysine and L-threonine to the diet did not show significant effect on these parameters compared to $\operatorname{diet} 7(\mathrm{p}>0.05)$.

\section{DISCUSSION}

Based on the growth response data calculated by the broken line analysis presented in this report, 57.64\% FM could be replaced by SPI without significantly affecting the WGR, FCR and survival rate of juvenile Amur sturgeon, and this fish is able to effectively utilize appropriate levels of SPI as the main protein ingredient in diet. But all growth parameters were significantly lower for fish fed diet with $75 \%$ of FM protein replaced. The use of alternative protein sources is generally limited by three main factors: low feed intake, low feed digestibility and imbalance of essential amino acids (EAA) (Zou, 2012). The activities of pepsin, trypsin and amylase in intestine significantly decreased among dietary treatments $(75,87.5$ and $100 \%$ substitution), suggesting the feed digestibility decreased with increasing

Table 3. Effects of replacement of fish meal with SPI on the digestive enzyme activities in Amur sturgeon*

\begin{tabular}{|c|c|c|c|c|c|c|c|c|c|}
\hline \multirow{2}{*}{ Group } & \multicolumn{3}{|c|}{ Protease (U/g protein) } & \multicolumn{3}{|c|}{ Lipase (U/g protein) } & \multicolumn{3}{|c|}{ Amylase (U/g protein) } \\
\hline & Foregut & Mid-gut & Hindgut & Foregut & Mid-gut & Hindgut & Foregut & Mid-gut & Hindgut \\
\hline Diet 1 & $974.03 \pm 10.11^{\mathrm{b}}$ & $353.02 \pm 10.01^{\mathrm{b}}$ & $511.54 \pm 9.25^{\mathrm{b}}$ & $769.43 \pm 8.58^{\mathrm{b}}$ & $663.15 \pm 10.56^{\mathrm{c}}$ & $423.52 \pm 9.23^{\mathrm{b}}$ & $74.68 \pm 10.14^{\mathrm{b}}$ & $55.09 \pm 12.12^{\mathrm{c}}$ & $33.42 \pm 5.19^{\mathrm{b}}$ \\
\hline Diet 2 & $961.98 \pm 9.13^{\mathrm{b}}$ & $834.19 \pm 13.02^{\mathrm{b}}$ & $494.07 \pm 10.24^{\mathrm{b}}$ & $755.59 \pm 9.83^{\mathrm{b}}$ & $647.34 \pm 12.87^{\mathrm{c}}$ & $411.84 \pm 10.14^{\mathrm{b}}$ & $73.92 \pm 9.11^{\mathrm{b}}$ & $51.80 \pm 13.22^{\mathrm{c}}$ & $30.36 \pm 6.11^{\mathrm{b}}$ \\
\hline Diet 3 & $948.85 \pm 13.14^{\mathrm{b}}$ & $825.78 \pm 9.21^{\mathrm{b}}$ & $488.96 \pm 12.28^{b}$ & $731.35 \pm 9.45^{\mathrm{b}}$ & $634.98 \pm 11.81^{\mathrm{c}}$ & $402.76 \pm 12.11^{\mathrm{b}}$ & $70.04 \pm 8.12^{\mathrm{b}}$ & $53.65 \pm 10.03^{\mathrm{c}}$ & $31.78 \pm 9.15^{\mathrm{b}}$ \\
\hline Diet 4 & $962.14 \pm 9.23^{\mathrm{b}}$ & $812.23 \pm 10.15^{\mathrm{b}}$ & $476.97 \pm 11.18^{\mathrm{b}}$ & $721.68 \pm 9.67^{b}$ & $615.29 \pm 12.39^{\mathrm{bc}}$ & $385.56 \pm 10.34^{\mathrm{b}}$ & $68.54 \pm 9.16^{\mathrm{b}}$ & $51.74 \pm 11.13^{\mathrm{c}}$ & $29.08 \pm 5.12^{\mathrm{b}}$ \\
\hline Diet 5 & $862.58 \pm 12.15^{\mathrm{a}}$ & $763.84 \pm 8.03^{\mathrm{a}}$ & $428.08 \pm 9.21^{\mathrm{a}}$ & $657.54 \pm 13.75^{\mathrm{a}}$ & $564.57 \pm 10.58^{\mathrm{b}}$ & $342.08 \pm 9.44^{\mathrm{a}}$ & $46.29 \pm 12.21^{\mathrm{a}}$ & $35.37 \pm 9.11^{\mathrm{b}}$ & $20.01 \pm 7.19^{\mathrm{a}}$ \\
\hline Diet 6 & $841.14 \pm 11.17^{\mathrm{a}}$ & $745.43 \pm 14.11^{\mathrm{a}}$ & $403.19 \pm 13.26^{\mathrm{a}}$ & $626.51 \pm 10.59^{\mathrm{a}}$ & $545.64 \pm 8.58^{\mathrm{a}}$ & $324.63 \pm 13.23^{\mathrm{a}}$ & $43.31 \pm 8.15^{\mathrm{a}}$ & $24.26 \pm 11.15^{\mathrm{a}}$ & $18.34 \pm 4.11^{\mathrm{a}}$ \\
\hline Diet 7 & $823.71 \pm 9.23^{\mathrm{a}}$ & $737.63 \pm 13.12^{\mathrm{a}}$ & $387.11 \pm 9.16^{\mathrm{a}}$ & $611.57 \pm 10.87^{\mathrm{a}}$ & $521.63 \pm 9.76^{\mathrm{a}}$ & $312.98 \pm 8.51^{\mathrm{a}}$ & $38.57 \pm 10.08^{\mathrm{a}}$ & $22.56 \pm 9.16^{\mathrm{a}}$ & $17.02 \pm 3.13^{\mathrm{a}}$ \\
\hline Diet 8 & $816.36 \pm 13.15^{\mathrm{a}}$ & $736.93 \pm 9.15^{\mathrm{a}}$ & $392.08 \pm 10.21^{\mathrm{a}}$ & $618.75 \pm 8.67^{\mathrm{a}}$ & $517.43 \pm 12.63^{\mathrm{a}}$ & $318.77 \pm 8.78^{\mathrm{a}}$ & $40.93 \pm 13.11^{\mathrm{a}}$ & $23.83 \pm 9.12^{\mathrm{a}}$ & $17.28 \pm 2.12^{\mathrm{a}}$ \\
\hline
\end{tabular}

* Values are mean \pm standard deviation. Different small letter superscripts in the same column means significant differences ( $<<0.05$ ); values within different organs for each digestive enzyme in the same row with different capital letter superscripts mean significant difference ( $\mathrm{p}<0.05$ ).

Table 4. Effects of replacement of fish meal with SPI on the serum biochemical parameters of Amur sturgeon*

\begin{tabular}{|c|c|c|c|c|c|c|c|c|}
\hline Parameters & Diet 1 & Diet 2 & Diet 3 & Diet 4 & Diet 5 & Diet 6 & Diet 7 & Diet 8 \\
\hline $\mathrm{TP}(\mathrm{g} / \mathrm{L})$ & $21.03 \pm 2.31^{\mathrm{d}}$ & $21.13 \pm 1.15^{\mathrm{d}}$ & $18.76 \pm 3.14^{\mathrm{cd}}$ & $17.24 \pm 1.13^{\mathrm{bc}}$ & $15.79 \pm 2.21^{\mathrm{ab}}$ & $14.18 \pm 3.16^{\mathrm{a}}$ & $14.12 \pm 1.06^{\mathrm{a}}$ & $14.05 \pm 2.15^{\mathrm{a}}$ \\
\hline ALB (g/L) & $10.69 \pm 1.34^{\mathrm{a}}$ & $11.03 \pm 1.16^{\mathrm{a}}$ & $9.55 \pm 2.23^{\mathrm{a}}$ & $9.21 \pm 1.46^{\mathrm{a}}$ & $8.90 \pm 2.29^{\mathrm{a}}$ & $8.57 \pm 0.67^{\mathrm{a}}$ & $8.39 \pm 0.87^{\mathrm{a}}$ & $8.42 \pm 0.17^{\mathrm{a}}$ \\
\hline GLB (g/L) & $10.34 \pm 1.95^{\mathrm{c}}$ & $10.10 \pm 2.23 \mathrm{c}$ & $9.20 \pm 1.19^{\mathrm{bc}}$ & $8.03 \pm 3.03^{\mathrm{abc}}$ & $6.89 \pm 2.08^{\mathrm{ab}}$ & $5.62 \pm 1.04^{\mathrm{a}}$ & $5.73 \pm 2.13^{\mathrm{a}}$ & $5.63 \pm 3.04^{\mathrm{a}}$ \\
\hline $\operatorname{ALP}(g / L)$ & $125.51 \pm 0.21^{\mathrm{a}}$ & $130.14 \pm 0.17^{\mathrm{ab}}$ & $138.35 \pm 0.12^{\mathrm{bc}}$ & $153.23 \pm 0.14^{\mathrm{c}}$ & $160.47 \pm 0.07^{\mathrm{c}}$ & $166.18 \pm 0.18^{\mathrm{cd}}$ & $187.61 \pm 0.11^{\mathrm{d}}$ & $176.75 \pm 0.13^{\mathrm{d}}$ \\
\hline
\end{tabular}

* Values are mean \pm standard deviation. Means in the same row with different superscripts are significantly different (p0.05). 
SPI. Soy protein usually contains protease inhibitors, predominantly a trypsin inhibitor, and trypsin is a known indicator of growth rate and conversion efficiency in cod (Lemieux et al., 1999), and it is also related to nutritional condition and digestive capacity in herring larvae (Ueberschaer and Clemmesen, 1992; Ueberschaer et al., 1992). Olli et al. (1994) demonstrated that the ingestion of soybean trypsin inhibitor resulted in significant reduction of protein digestibility and weight gain. It has been demonstrated that when protease inhibitors bind to proteases, it causes the pancreas to secrete greater amounts of digestive enzymes to overcome the inhibitors and digest the dietary protein (Haard et al., 1996). As the pancreas is the main secretory gland of fish, pancreatic hypertrophy and hyperplasia might affect protease, lipase and amylase activity. The decline of enzyme activities is correlated with growth performance and therefore might explain the observed decrease in growth rate (Xu et al., 2009). Therefore, lower feed digestibility was likely one of the main factors, which decreased the growth of sturgeon fed with elevated levels of dietary SPI.

In the present paper, sturgeon fed a $296.00 \mathrm{~g} / \mathrm{Kg}$ SPI diet never reached the growth rates even with supplements of L-methionine, L-lysine and L-threonine. Methionine and lysine were the most limiting amino acids in plant protein, and methionine is known to be the first-limiting amino acid of soy protein in fish (Mambrini et al., 1999). Supplemental L-lysine and L-methionine in fish diets had variable success. Viola and Lahav (1991) stated that the addition of L-lysine to a diet deficient in lysine for common carp improved fish growth when compared to a commercial diet. Shiau et al. (1987) reported that the addition of supplemental methionine improves the growth of tilapia. This is in contrast to Bai and Gatlin (1994), who reported that supplements of L-lysine in a diet with $25 \%$ crude protein from soy did not improve the growth of catfish. The nutritional value of free amino acid (FAA) as compared to protein-bound amino acid (AA) is still controversial in fish nutrition for many species (Dabrowski and Guderley, 2002). The most popular one is based on the fact that FAA do not have to be released from protein by intestinal digestion and can therefore be immediately absorbed in the first part of the intestine (Cowey and Walton, 1988). After absorption, as the size of the FAA pool remains relatively constant during the postprandial phase, the protein synthesis capacity may be exceeded by the high AA appearance rate in the FAA pool of fish fed FAA-rich diets.

The innate immune system is a fundamental defense mechanism of fish. As blood is a patho-physiological reflector of the whole body, blood parameters are therefore important in diagnosing the status of fish (Decie and Lewis, 1991). As a first line of defense, various peptides, such albumin and globulin are present in the serum, where they prevent adherence of and colonization by microorganisms (Alexandar and Ingram, 1992), which could lead to infection and disease. ALP belongs to the nonplasma specific enzymes that can be found not only in blood plasma but also within the tissue of the liver, gills, kidneys, muscles and other organs, whereas it mainly existed in liver (Asadi et al., 2006). ALP levels may give specific information about organ dysfunction (Anver, 2004; Wagner and Congleton, 2004), and it is considered to be indicative of liver impairment when its serum levels increase (Burtis and Ashwood, 1996). Increasing levels of dietary SPI significantly affect the serological characteristics of Amur sturgeon in this study, the levels of serum TP and GLB decreased significantly with increasing dietary SPI, while ALP activity showed the reverse tendency. The plasma protein level can be considered an index of fluid volume disturbances (Goss and Wood, 1988), and it may also be used as an energy source during severe stress (Vajcova et al., 1998; Rehulka, 2000). A decline in serum protein level may be related to impaired food intake or an increased energy cost of homeostasis, tissue repair and detoxification mechanisms during stress (Neff, 1985). The data obtained in the current paper may be due to reduced protein synthesis or a protein breakdown caused by cirrhosis, intestinal mucosal disruption or an increase in the rate of protein synthesis as a general adaptation tactic to bind excess trypsin inhibitors in the plasma, which resulted from high levels of SPI in the diet. Results demonstrated that SPI exceeding $148.00 \mathrm{~g} / \mathrm{kg}$ in a diet might have adverse effects on the immune system.

\section{CONCLUSIONS}

This paper demonstrated that under current experimental conditions as much as $57.64 \%$ of the FM protein in a diet could be replaced by SPI in feed without compromising growth performance, the addition of crystalline amino acid to a diet without FM did not contribute to the growth and digestive performance of juvenile Amur sturgeon.

\section{ACKNOWLEDGEMENTS}

This study was supported by Special Fund for Agroscientific Research in the Public Interest (201003055), China.

\section{REFERENCES}

Alexandar, J. B. and G. A. Ingram. 1992. Noncellular non-specific defense mechanisms of fish. Annu. Rev. Fish Dis. 2:249-279.

Anver, C. E. 2004. Blood chemistry (electrolytes, lipoprotein and enzymes) values of black scorpion fish (Scorpaena porcus, 1758) in the Dardanelles. Turkey. J. Biol. Sci. 4:716-719. 
Ao, X., H. J. Kim, Q. Meng, W. L. Yan, J. H. Cho and I. H. Kim. 2010. Effects of diet complexity and fermented soy protein on growth performance and apparent ileal amino acid digestibility in weanling pig. Asian-Aust. J. Anim. Sci. 23:1496-1502.

Asadi, F., M. Masoudifard, A. Vajhi, K. Lee, M. Pourkabir and P. Khazraeinia. 2006. Serum biochemical parameters of Acipenser persicus. Fish Physiol. Biochem. 32:43-47.

Bai, S. C. and D. M. Gatlin. 1994. Effects of L-lysine supplementation of diets with different protein levels and sources on channel catfish, Ictalurus puncrarus (Rafinesque). Aquac. Res. 25:465-474.

Burtis, C. A. and E. R. Ashwood. 1996. Tietz Fundamentals of Clinical Chemistry. W.B. Saunders Company, Philadelphia.

Carter, C. G. and R. C. Hauler. 2000. Fish meal replacement by plant meals in extruded feeds for Atlantic salmon, Salmo salar L. Aquaculture. 185:299-311.

Cowey, C. B. and M. J. Walton. 1988. Studies on the uptake of $\left({ }^{14} \mathrm{C}\right)$ amino acids derived from both dietary $\left({ }^{14} \mathrm{C}\right)$ protein and dietary $\left({ }^{14} \mathrm{C}\right)$ amino acids by rainbow trout, Salmo gairdneri Richardson. J. Fish Biol. 33:293-305.

Dabrowski, K. and H. Guderley. 2002. Intermediary metabolism. In: Fish Nutrition (Ed. J. E. Halver and R. W. Hardy). Academic Press, San Diego, CA, USA, pp. 310-367.

Decie, S. IV. and S. M. Lewis. 1991. Practical haematology, (VII edn). Churchill, Livingston.

El-Saidy, D. M. S. and M. M. Gaber. 1997. Total replacement of fish meal by soybean meal, with various percentages of supplemental L-methionine, in diets for Nile tilapia (oreochromisniloticus, L.). Annals of Agriculture Science of Moshtohor 35:1 223-1 238.

El-Saidy, D. M. S. and M. M. Gaber. 2002. Complete replacement of fishmeal by soybean with the dietary L-lysine supplementation in Nile tilapia fingerlings. J. World Aquac. Soc. 33:297-306.

Floreto, E. A. T., R. C. Bayer and P. B. Brown. 2000. The effects of soybean-based diets, with and without amino acid supplementation, on growth and biochemical composition of juvenile American Lobster, Homarus americanus. Aquaculture 189:211-235.

Gjellesvik, D. R., D. Lombardo and B. T. Walther. 1992. Pancreatic bile salt dependent lipase from cod (Gadus morhua): purification and properties. Biochim. Biophys. Acta. 1124:123-134.

Goss, G. G. and C. M. Wood. 1988. The effects of acid and acid/aluminium exposure on circulating plasma cortisol levels and other blood parameters in the rainbow trout, Salmo gairdneri. J. Fish Biol. 32:63-76.

Haard, N. F., L. E. Dimes, R. E. Arndt and F. M. Dong. 1996. Estimation of protein digestibility. IV. Digestive proteinases from the pyloric caeca of coho salmon (Oncorhynchus kisutch) fed diets containing soybean meal. Comp. Biochem. Physiol. B 115:533-540.

Kaushik, S. J. 1990. Use of alternative protein sources for the intensive rearing of carnivorous fish. In: Mediterranean Aquaculture (Ed. R. Flos, L. Tort and P. Torres), pp. 125-138. Ellis Horwood.

Krogdahl, A. and H. Holm. 1981. Soybean protease inhibitors and human proteolytic enzymes: selective inactivation of inhibitors by treatments with human gastric juice. J. Nutr. 111:2045-2051.
Lemieux, H., P. U. Blier and J. D. Dutil. 1999. Do digestive enzymes set a physiological limit on growth rate and food conversion efficiency in the Atlantic cod (Gadus morhua)? Fish Physiol. Biochem. 20:293-303.

Liu, Y. M., J. Z. Zhu, H. Y. Wu and D. Z. Shi. 1991. Studies on digestive enzymes and amino acid of larval and post larval stages of prawn Penaeus chinensis. Oceanol. Lminol. Sin. 22:571-575.

Mambrini, M., A. J. Roem, J. P. Cravedi, J. P. Lalles and S. J. Kaushik. 1999. Effect of replacing fish meal with soy protein concentrate and of DL-methionine supplementation in highenergy, extruded diets on the growth and nutrient utilization of rainbow trout, Oncorhynchus mykiss. J. Anim. Sci. 77:29902999.

Min, B. J., J. H. Cho, Y. J. Chen, H. J. Kim, Y. S. Yoo, C. Y. Lee, B. C. Park, J. H. Lee and I. H. Kim. 2009. Effects of fermented soy protein on growth performance and blood protein contents in nursery pigs. Asian-Aust. J. Anim. Sci. 22:1038-1042.

Morales, A. E., G. Cardenete, M. de la Higuera and A. Sanz. 1994. Effects of dietary protein source on growth, feed conversion and energy utilisation in rainbow trout, Oncorhynchus mykiss. Aquaculture 124:117-126.

Naylor, R. L., R. J. Goldberg, J. H. Primavera, N. Kautsky, M. C. M. Beveredge, J. Clay, C. Folke, J. Lubchenco, H. Mooney and M. Troell. 2000. Effects of aquaculture on world fish supplies. Nature 405:1017-1 024

Neff, J. M. 1985. Use of biochemical measurement to detect pollutant-mediated damage to fish. ASTM Spec Tech Pub. 1 854:155-183

Olli, J., K. Hjelmeland and A. Krogdahl. 1994. Soybean trypsin inhibitor in diets for Atlantic salmon (Salmo salar, L): Effects on nutrient digestibilities and in pyloric caeca homogenate and intestinal content. Comp. Biochem. Physiol. A 109:923-928.

Rehulka, J. 2000. Influence of astaxanthin on growth rate, condition, and some blood indices of rainbow trout, Oncorhynchus mykiss. Aquaculture 190:27-47.

Shiau, S. Y., J. I. Chuang and C. L. Sun. 1987. Inclusion of soybean meal in tilapia, 0 . niloricus $\mathrm{X} 0$. aureus diets at two protein levels. Aquaculture 65:251-261.

Ueberschaer, B. and C. Clemmesen. 1992. A comparison of the nutritional condition of herring larvae as determined by two biochemical methods - tryptic enzyme activity and RNA/DNA ratio measurements. ICES J. Mar. Sci. 49:245-249.

Ueberschaer, B., B. H. Pedersen and K. Hjelmeland. 1992. Quantification of trypsin with radioimmunoassay in herring larvae (Clupea harengus) compared with a highly sensitive fluorescent technique to determine tryptic enzyme activity. Mar. Biol. 113:469-473.

Vajcova, V., S. Navrati and M. Palıkova. 1998. The effect of intraperitoneally applied puremicrocystin-LRon haematological, biochemical and morphological indices of silver carp (Hypophthalmichthys molitrix Val.). Acta Vet. Brno. 67:281287.

Viola, S. and E. Lahav. 1991. The protein sparing effect of synthetic lysine in practical carp feeds. Fish nutrition in practice. IV International Symposium on Fish Nutrition and Feeding, Bianitz, France. Abstract.

Wagner, T. and J. L. Congleton. 2004. Blood chemistry correlates of nutritional condition, tissue damage, and stress in migrating 
Juvenile Chinook salmon (Onchorhynchus tshawytscha). Can. J. Fish. Aquat. Sci. 61:1066-1074.

Whitaker, J. R. 1994. Principles of enzymology for the food sciences. $2^{\text {nd }}$ ed. Marcel Dekker, New York, USA.

Xu, B. H., Y. B. Wang, J. R. Li and Q. Lin. 2009. Effect of prebiotic xylooligosaccharides on growth performances and digestive enzyme activities of allogynogenetic crucian carp (Carassius auratus gibelio). Fish Physiol. Biochem. 35:351357.

Zhang, J. X., X. Q. Zhou, X. Q. Ni and Y. Liu. 2008. Effect of soybean protein isolate on growth performance and intestine of Cyprinus carpio var. jian juveniles. J. Fish. China. 32:84-90.
Zhuang, P., B. Kynard, L. Zhang, T. Zhang, Z. Zhang and D. Li. 2002. Overview of biology and aquaculture of Amur sturgeon (Acipenser schrenckii) in China. J. Appl. Ichthyol. 18:659-664.

Zeitoun, H. I., D. E. Ullrey and W. T. Magee. 1976. Quantifying nutrient requirements of fish. J. Fish. Res. Board Can. 33:167172

Zou, Y. R., Q. H. Ai, K. S. Mai, W. B. Zhang, Y. J. Zhang and W. Xu. 2012. Effects of brown fish meal replacement with fermented soybean meal on growth performance, feed efficiency and enzyme activities of Chinese soft-shelled turtle, Pelodiscus sinensis. J. Ocean Univ. China. 11:227-235 (DOI 10.1007/s11802-012-1896-8). 